\title{
Efektifitas Modifikasi Ovitrap Model Kepanjen untuk Menurunkan Angka Kepadatan Larva Aedes aegypti di Malang
}

\section{The Effectiveness of Kepanjen Model Ovitrap Modification to Decrease the Density of Aedes aegypti Larvae in Malang}

\author{
Lilik Zuhriyah $^{1}$, Tri Baskoro TS², Hari Kusnanto ${ }^{3}$ \\ ${ }^{1}$ Laboratorium IImu Kesehatan Masyarakat Fakultas Kedokteran Universitas Brawijaya Malang \\ ${ }^{2}$ Bagian Parasitologi Fakultas Kedokteran Universitas Gadjah Mada Yogyakarta \\ ${ }^{3}$ Departemen Kedokteran Keluarga Fakultas Kedokteran Universitas Gadjah Mada Yogyakarta
}

\begin{abstract}
ABSTRAK
Ovitrap merupakan alat perangkap telur nyamuk yang sukses diaplikasikan di beberapa negara. Penyederhanaan model ovitrap telah dilakukan dan diaplikasikan di Kepanjen, Kabupaten Malang namun sampai saat ini kontribusinya dalam menurunkan kepadatan larva belum pernah dievaluasi. Penelitian ini bertujuan untuk membandingkan House Index, Container Index, Breteau Index, dan Density Index antara daerah perlakuan dan daerah kontrol serta sebelum dan sesudah intervensi, mengetahui trend jumlah telur nyamuk per ovitrap, serta mengidentifikasi jenis larva yang ditetaskan dari telur yang didapat dari ovitrap. Penelitian Eksperimen Kuasi dilakukan di 4 Rukun Warga (RW) dari kelurahan yang berbeda di Kotamadya Malang pada September 2013-Februari 2014 yang memiliki Incidence Rate (per 10.000 penduduk) DBD tertinggi dalam empat bulan pertama 2013 yaitu 11,89 untuk Jatimulyo; 10,52 untuk Merjosari; 31,57 untuk Sumbersari; dan 25,21 untuk Bandulan. Hasilnya menunjukkan bahwa angka kepadatan larva ( $\mathrm{HI}, \mathrm{BI}, \mathrm{Cl}$, dan DI) dua RW perlakuan lebih rendah secara signifikan $(\mathrm{p}<0,05)$ dibandingkan dua RW kontrol dengan Uji Mann Whitney. Kepadatan larva dan ratarata jumlah telur dari ovitrap sesudah aplikasi ovitrap lebih rendah dibandingkan sebelumnya. Sebagian besar telur yang terperangkap merupakan telur Aedes aegypti. Disimpulkan bahwa aplikasi ovitrap di 4 RW dari kelurahan di Malang efektif untuk menurunkan kepadatan larva dan dapat diterapkan sebagai salah satu cara pengendalian nyamuk Ae. aegypti.
\end{abstract}

Kata Kunci: Aedes aegypti, angka kepadatan jentik, ovitrap, jumlah telur

\begin{abstract}
Ovitrap is a tool to trap mosquito eggs that are successfully applied in several countries. Simplification of ovitrap model has been made and applied at Kepanjen Malang, but its contribution in reducing larval density has not been evaluated yet. This study aims to compare the House Index, Container Index, Breteau Index, and Density Index between the treatment area and the control area as well as before and after the intervention, to know the trend of the number of mosquito eggs per ovitrap, as well as to identify the species of larvae that have been hatched from eggs obtained from ovitraps. A quasi Experiment study was conducted in 4 neighbourhoods (RW) from different villages in Malang between September 2013February 2014 which have the highest Incidence Rate of DHF (per 10.000 population) in four first months i.e. 11,89 in Jatimulyo; 10,52 in Merjosari; 31,57 in Sumbersari; and 25,21 in Bandulan. The result shows that the larval density index $(\mathrm{HI}, \mathrm{BI}, \mathrm{Cl}$, and $\mathrm{DI})$ of two-neighbourhoods treatment was significantly lower $(p<0,05)$ compared to two neighbourhood controls by using Mann Whitney Test. The larvae density and the average number of eggs from ovitrap post ovitrap application were lower than the pre result. Most of the eggs trapped were eggs of Aedes aegypti. It could be concluded that ovitrap application in 4 neighbourhoods from villages in Malang is effective to reduce larval density index and could be apllied as one of methods of Ae. aegypti mosquitoes control.
\end{abstract}

Keywords: Aedes aegypti, larvae density, number of eggs, ovitrap

Korespondensi: Lilik Zuhriyah. Laboratorium IImu Kesehatan Masyarakat Fakultas Kedokteran Universitas Brawijaya Malang, Jl. Veteran Malang Jawa Timur Tel. (0341) 569117 Email: lilik.zuhriyah@gmail.com 


\section{PENDAHULUAN}

Penyakit Demam Berdarah Dengue (DBD) saat ini masih menjadi masalah kesehatan di Indonesia. Prevalensi kasus DBD klinis (berdasarkan diagnosis tenaga kesehatan dan keluhan responden) di tingkat nasional masih tergolong tinggi pada 2007 yaitu 0,6\% (rentang: 0,3\%o-2,5\%) dan menjadi penyebab kematian utama pada anak-anak (1). Provinsi Jawa Timur sebagai propinsi yang padat di Indonesia memiliki Incidence Rate (IR) DBD (per 100.000 penduduk) sebesar 21,72 penderita pada tahun 2012 yang meningkat dibandingkan tahun 2011 (2). Sebaliknya di kota Malang IR DBD tersebut menurun menjadi 17 penderita pada 2012 setelah sebelumnya mencapai 20 penderita pada 2011. Namun pada 2013 terjadi lonjakan IR DBD karena dari data penderita Januari hingga April saja didapatkan IR sebesar 32 penderita per 100.000 penduduk (3-7).

Pengendalian vektor menjadi pilihan utama pencegahan DBD mengingat sampai saat ini vaksin dan obat DBD masih terus dikembangkan (8). Pengendalian vektor dapat dilakukan dengan cara kimiawi, biologis, dan fisik. Namun cara kimiawi, seperti fogging masal, memberikan dampak negatif bagilingkungan.

Salah satu metode yang dapat digunakan sebagai alat survei dan alat pengendalian vektor nyamuk yang disarankan oleh WHO adalah perangkap telur nyamuk atau ovitrap $(8,9)$. Penggunaan ovitrap dengan air biasa dengan beberapa variasinya di Kamboja (10), Brazil (11), Thailand (12), dan Singapura (13) terbukti mampu memerangkap telur nyamuk. Meskipun ovitrap tidak bisa memprediksi kepadatan nyamuk dewasa, namun ovitrap cukup sensitif untuk daerah yang angka kepadatan vektornya rendah $(9,14)$. Bahkan ketika BI menunjukkan angka yang rendah, surveilans dengan ovitrap mampu menghasilkan index (yang mempertimbangkan keberadaan telur nyamuk yaitu Ovitrap Index) yang lebih sensitif dibandingkan $\mathrm{HI}$ dan $\mathrm{BI}$ seperti penelitian yang dilakukan di Taiwan dan Brazil $(14,15)$.

Kecenderungan nyamuk Ae. aegypti meletakkan telur (Oviposition) pertama kali diteliti oleh Fay and Perry kemudian dikembangkan menjadi autocidal ovitrap oleh Lok et al, dengan desain yang agak rumit $(16,17)$. Lok et al, menggunakan kontainer plastik hitam berukuran $9 \times 11,8 \mathrm{~cm}$ yang di dalamnya ditaruh pelampung berbentuk lingkaran yang mengambang di air atau media yang memungkinkan ada udara di bagian bawahnya. Diameter bagian alas dan atas sama. Dua potong papan kayu dengan posisi vertikal ditempatkan di dalamnya yang memungkinkan nyamuk betina yang penuh dengan telur dan siap bertelur (gravid) untuk meletakkan telurnya.

Hal ini mendorong dikembangkannya ovitrap dengan desain yang lebih sederhana. Ovitrap yang lebih sederhana telah dikembangkan oleh Puspita $\mathrm{H}$ dan diaplikasikan di SMPN 5 Kepanjen Malang (18). Ovitrap dari ember hitam dengan diameter bagian atas kurang lebih $25 \mathrm{~cm}$ dan tinggi $19 \mathrm{~cm}$ ini walaupun tidak menggunakan pelampung dan papan kayu namun tetap bisa berfungsi sebagai autocidal ovitrap karena tetap menggunakan kain kasa nyamuk sebagai penutup ovitrap. Kain kasa nyamuk ini juga berfungsi sebagai tempat bertelurnya nyamuk betina karena bagian tengah kain kasa akan basah jika ditekan ke dalam ovitrap hingga tercelup sebagian ke dalam air di dalamnya. Ovitrap ini sama-sama menggunakan air biasa sebagai atraktan nyamuk sekaligus media pertumbuhan telur. Telur yang menempel di kain kasa dan menetas akan berkembang menjadi nyamuk di bagian bawah kasa nyamuk dan terperangkap di dalamnya. Namun demikian sampai saat ini evaluasi secara sistematis tentang efektifitasnya di dalam menurunkan angka kepadatan vektor nyamuk belum dilakukan.

Evaluasi secara laboratoris terhadap ovitrap model Kepanjen menunjukkan bahwa penggunaan air ledeng dan air sumur masih dapat menarik nyamuk betina untuk bertelur di dalamnya. Di samping itu penggunaan kain kasa nyamuk sebagai penutup ovitrap ternyata kurang aman dibandingkan kain nylon karena masih memungkinkan nyamuk bisa keluar ovitrap melalui lubang kasa nyamuk (19). Karena itu dalam penelitian ini digunakan ovitrap model Kepanjen yang telah dimodifikasi penutupnya dengan kain nylon.

Tujuan dari penelitian ini adalah untuk membandingkan House Index ( $\mathrm{HI})$, Container Index $(\mathrm{Cl})$, Breteau Index (BI), dan Density Index (DI) antara daerah yang mengaplikasikan ovitrap model Kepanjen dan daerah yang tidak mengaplikasikannya serta sebelum dan sesudah intervensi, mengetahui trend jumlah telur nyamuk per ovitrap, serta mengidentifikasi jenis larva yang ditetaskan dari telur yang didapat dari ovitrap.

\section{METODE}

\section{Desain Penelitian}

Penelitian ini merupakan penelitian Eksperimen Kuasi dengan desain Non Randomized Pre test-post test control group karena tidak dilakukan kontrol terhadap variabelvariabel perancu di daerah penelitian. Penelitian dilakukan mulai November 2013 sampai Februari 2014. Pemilihan daerah penelitian ditentukan berdasarkan data IR DBD tertinggi di tingkat kelurahan di Kota Malang dan pertimbangan tingkat partisipasi warga oleh puskesmas setempat (non randomized). Setelah ditentukan 4 kelurahan, selanjutnya dipilih lagi satu Rukun Warga (RW) per kelurahan dengan jumlah penderita DBD terbanyak. RW terpilih dialokasikan dalam kelompok kontrol dan kelompok perlakuan. Kelompok kontrol adalah RW yang tidak mengaplikasikan ovitrap namun disurvei larva untuk mengetahui $\mathrm{HI}, \mathrm{Bl}, \mathrm{Cl}$, dan $\mathrm{DI}$, sedangkan kelompok perlakuan adalah RW yang mengaplikasikan ovitrap dan disurvei larva untuk mengetahui $\mathrm{HI}, \mathrm{Bl}, \mathrm{Cl}$, dan $\mathrm{DI}$. Untuk daerah kontrol terpilih adalah RW 2 Jatimulyo (IR $\mathrm{DBD}=11,89$ per 10.000 penduduk) dan RW 1 Merjosari (IR $\mathrm{DBD}=10,52$ per 10.000 penduduk), sedangkan daerah perlakuan adalah RW 2 Sumbersari (IR DBD=31,57per 10.000 penduduk) (20) dan RW 6 Bandulan (IR DBD $=25,21$ per 10.000 penduduk) (21).

\section{Ovitrap Model Kepanjen}

Ovitrap yang diaplikasikan adalah ovitrap model Kepanjen yang terbuat dari ember hitam (diameter $25 \mathrm{~cm}$ dan tinggi $19 \mathrm{~cm}$ ) berisi air PDAM atau sumur lebih kurang $2 / 3$ tinggi ember, kemudian ditutup dengan kain nylon (19) yang diikat di bagian atas ember. Bagian tengah kain nylon ditekan ke bagian dalam ember hingga tercelup sebagian ke dalam air. Bagian tengah nylon ditempeli kertas saring warna putih untuk memudahkan menghitung jumlah telur nyamuk yang menempel di kertas saring.

\section{Penempatan Ovitrap}

Ovitrap ditempatkan di sekolah dasar (SD) yang ada di RW tersebut dan di rumah kader kesehatan/siswa setempat mulai 31 Oktober 2013-19 Februari 2014. Setiap satu SD yang ada di RW penelitian mendapatkan 10 ovitrap yang 
penempatannya di dalam dan di luar ruangan, sedangkan setiap rumah kader kesehatan atau siswa mendapatkan 2 ovitrap yang ditempatkan di dalam rumah dan di luar rumah. Jumlah kader kesehatan/siswa yang mendapatkan ovitrap di masing-masing RW perlakuan adalah 8 orang. Pernyataan kesediaan berpartisipasi dalam penelitian diberikan oleh pemilik rumah (kader kesehatan dan orang tua siswa) setelah sebelumnya diberikan penjelasan tentang penelitian tersebut, sedangkan dari sekolah pernyataan kesediaan berpartisipasi diberikan oleh kepala sekolah. Kader kesehatan dan siswa mendapat reward untuk partisipasinya di dalam penelitian. Instalasi dan penempatan ovitrap di rumah kader kesehatan/siswa dilakukan oleh masing-masing pemilik rumah setelah sebelumnya mendapatkan pembekalan oleh peneliti. Untuk instalasi dan penempatan ovitrap di sekolah dilakukan oleh peneliti bersama guru dan siswa.

\section{Observasi Ovitrap}

Observasi dilakukan seminggu sekali untuk mengganti kertas saring yang basah dengan kertas saring yang baru mengingat siklus hidup nyamuk adalah 7 hari. Kertas saring yang telah diambil dikeringkan kemudian dihitung jumlah telur nyamuknya. Telur yang telah dihitung kemudian ditetaskan dengan merendamnya dengan air sumur untuk kemudian diidentifikasi jenis larvanya. Perhitungan jumlah telur nyamuk dan identifikasi jenis larva dilakukan dengan menggunakan mikroskop binokular di Laboratorium Parasitologi Fakultas Kedokteran Universitas Brawijaya.

Identifikasi larva dilakukan setelah merendam kertas saring beberapa ovitrap positif telur yang didapat dari sampling terhadap lebih kurang $70 \%$ dari 16 periode pengambilan kertas saring ovitrap. Identifikasi larva dilakukan secara sampling dengan memeriksa lebih kurang 5 larva per gelas perendaman kertas saring ovitrap. Larva Culicine (misalnya Aedes dan Culex) dibedakan dari larva Anopheline dari adanya tabung yang memanjang untuk bernafas yang disebut siphon. Larva Aedes dan Culex dalam kelompok Culicine sendiri dibedakan dari bentuk siphonnya dimana siphon Aedes lebih pendek dengan hanya satu rumpun tunggal setae. Sebaliknya, siphon Culex lebih panjang dengan beberapa rumpun setae. Untuk menentukan jenis larva Aedes dilakukan perbandingan bentuk comb scales (comb teeth) pada segmen ke 8 dari abdomen dan bentuk pecten teeth (22).

\section{Survei Angka Kepadatan Larva Nyamuk}

Survei larva nyamuk dilakukan 1 minggu sekali terhadap lebih kurang 50 rumah per RW untuk menghitung $\mathrm{HI}, \mathrm{Cl}$, $\mathrm{BI}$, dan DI. Peralatan yang digunakan untuk survei adalah senter dan form observasi. Surveyor adalah mahasiswa yang telah dilatih dengan didampingi oleh kader kesehatan setempat.

\section{Analisis Data}

Analisis data dilakukan dengan menggunakan data survei mingguan sebagai unit analisis. Grafik moving average 3 mingguan digunakan untuk mengetahui trend angka kepadatan vektor. Uji beda masing-masing indeks kepadatan vektor nyamuk antar kelompok dilakukan dengan Mann Whitney karena dengan uji KolmogorovSmirnov terbukti data tidak terdistribusi normal.

Penelitian ini telah disetujui oleh Komite Etik Fakultas Kedokteran Universitas Brawijaya Malang (No. 441/EC/KEPK-S3-JK/08/2013).

\section{HASIL}

Dalam penelitian ini pemilihan lokasi penelitian didasarkan pada sebaran penderita per kelurahan yang menunjukkan bahwa lokasi penelitian memiliki IR DBD yang termasuk dalam kategori tinggi atau berdekatan dengan kelurahan dengan IR DBD tinggi (Gambar 1).

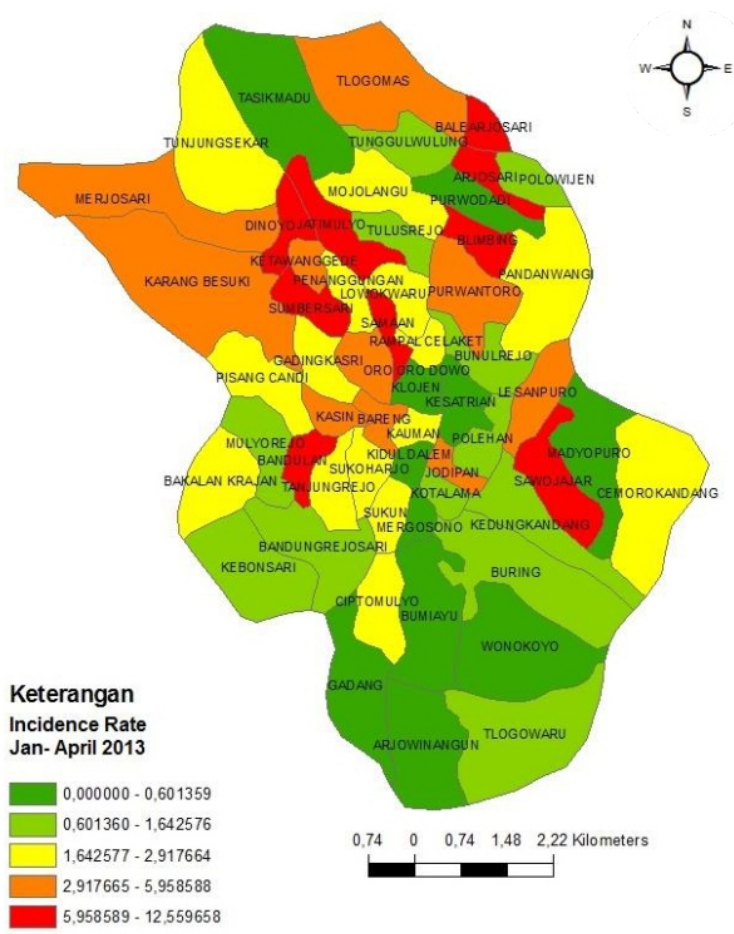

Gambar 1. Incidence Rate (IR) DBD per kelurahan kota Malang, Januari- April 2013 (4,7)

Tabel 1. Profil lokasi penelitian

\begin{tabular}{|c|c|c|c|c|c|}
\hline \multirow[b]{2}{*}{ No } & \multirow[b]{2}{*}{ Variabel } & \multicolumn{2}{|c|}{ Kontrol } & \multicolumn{2}{|c|}{ Perlakuan } \\
\hline & & $\begin{array}{c}\text { RW } 2 \\
\text { Jatimulyo }\end{array}$ & RW 1 Merjosari & $\begin{array}{c}\text { RW } 2 \\
\text { Sumbersari }\end{array}$ & $\begin{array}{c}\text { RW } 6 \\
\text { Bandulan }\end{array}$ \\
\hline 1 & Jumlah RT & 10 & 3 & 5 & 8 \\
\hline 2 & Jumlah Penduduk & 3.365 & 951 & 1.584 & 1.556 \\
\hline 3 & Jumlah rumah & 838 & 208 & 362 & 385 \\
\hline 4 & $\begin{array}{l}\text { Kepadatan Hunian per Rumah } \\
\text { ( } \Sigma \text { penduduk } / \Sigma \text { rumah) }\end{array}$ & 4.02 & 4.57 & 4.38 & 4.04 \\
\hline 5 & Tipe pemukiman & $\begin{array}{l}7 \text { RT perkampungan, } 3 \\
\text { RT non perkampungan* }\end{array}$ & 3 RT perkampungan* & $\begin{array}{c}5 \mathrm{RT} \\
\text { perkampungan* }\end{array}$ & $\begin{array}{l}2 \text { RT perkampungan,6 } \\
\text { RT non perkampungan* }\end{array}$ \\
\hline
\end{tabular}

Sumber no 1-5: Data Kader/ RW Keterangan: *= Tipe pemukiman perkampungan ditandai dengan tidak terstrukturnya susunan peta rumahrumah; tipe non perkampungan ditandai dengan terstrukturnya susunan peta rumah-rumah baikkarena termasuk perumahan maupun daerah kavling. 
Tabel 2. Perbandingan $\mathrm{HI}, \mathrm{BI}$, dan $\mathrm{Cl}$ antara kelompok kontrol dan kelompok perlakuan serta antara sebelum dan sesudah perlakuan

\begin{tabular}{|c|c|c|c|c|c|c|c|c|c|}
\hline \multirow[b]{2}{*}{ Indeks } & \multicolumn{2}{|c|}{ Sebelum (Survei 1) } & \multicolumn{2}{|c|}{ Sesudah (Survei 18) } & \multicolumn{2}{|c|}{ Penurunan } & \multicolumn{3}{|c|}{ Mean Rank } \\
\hline & Kontrol & Perlakuan & Kontrol & Perlakuan & Kontrol & Perlakuan & $\begin{array}{c}\text { Kontrol } \\
(n=16)\end{array}$ & $\begin{array}{c}\begin{array}{c}\text { Perlakuan } \\
(n=16)\end{array} \\
\end{array}$ & $\mathbf{p}$ \\
\hline $\mathrm{HI}$ & 27,12 & 16,08 & 23,36 & 2,94 & 3,75 & 13,14 & 20,25 & 12,75 & 0,024 \\
\hline BI & 37,29 & 20,28 & 30,84 & 2,94 & 6,45 & 17,34 & 20,34 & 12,66 & 0,020 \\
\hline $\mathrm{Cl}$ & 8,52 & 5,70 & 13,98 & 0,89 & $-5,47$ & 4,81 & 21,00 & 12,00 & 0,007 \\
\hline DI & 4,00 & 3,33 & 4,00 & 1,00 & 0,00 & 2,33 & 20,09 & 12,91 & 0,027 \\
\hline $\begin{array}{l}\text { Rata-rata Jumlah } \\
\text { Telur per Ovitrap }\end{array}$ & TD & 147,09 & TD & 20,33 & TD & 126,76 & & & \\
\hline
\end{tabular}

Keterangan: $T D \rightarrow$ Tidak Dilakukan

Tampak bahwa Jatimulyo, Sumbersari, dan Bandulan merupakan kelurahan dengan IR DBD yang tergolong paling tinggi, sedangkan Merjosari meskipun IR DBD nya tidak tergolong tertinggi namun lokasi RW penelitian berdekatan dengan Dinoyo, kelurahan dengan IR DBD yang tergolong paling tinggi .

Secara umum gambaran mengenai lokasi penelitian tampak pada Tabel 1. Pada Tabel 1 tampak bahwa jumlah RT di kedua kelompok penelitian sama, demikian pula dengan kepadatan hunian per rumah masing-masing kelompok dapat dikatakan relatif sama. Untuk tipe pemukiman dapat dikatakan relatif sama karena rumah di perumahan/kavling yang dimaksud bukanlah tipe yang luas. Karakteristik sosial budaya masing-masing RW dapat dikatakan sama karena sama-sama berasal dari etnis Jawa.

Survei jentik selama 2 minggu sebelum ovitrap diaplikasikan menunjukkan bahwa tidak ada beda $\mathrm{HI}$ $(p=1), B I(p=1), C l(p=0,439)$, dan $D I(p=0,683)$ antara kedua kelompok penelitian. Artinya kedua kelompok tersebut sepadan untuk dibandingkan.

Jumlah ovitrap yang diamati tiap minggunya dapat bervariasi karena adanya masalah teknis di lapangan. Masalah ini ditemui baik untuk aplikasi di sekolah maupun di masyarakat. Sampling terhadap ovitrap di sekolah menunjukkan bahwa $89,7 \%$ terpasang baik, 2,7\% terguling/kotor, 0,5\% belum dipasang, 0,5\% dibuang, $1,1 \%$ kertas saring tidak tercelup, dan 5,4\% kertas saring hilang/rusak, sedangkan untuk ovitrap yang diinstalasi dan ditempatkan oleh kader kesehatan/siswa di rumahnya masing-masing menunjukkan bahwa 51,2\% terpasang baik, 4,9\% terguling/kotor, $24,4 \%$ belum dipasang, 7,3\% dibuang, 12,2\% kertas saring hilang/rusak.

Survei selama 16 minggu setelah ovitrap diaplikasikan menunjukkan hasil adanya penurunan indeks kepadatan vektor seperti pada Tabel 2.

Tampak bahwa kelompok kontrol dan kelompok perlakuan mengalami penurunan $\mathrm{HI}, \mathrm{BI}$, dan $\mathrm{Cl}$ (kecuali $\mathrm{Cl}$ pada kelompok kontrol). Namun penurunan yang tajam terjadi pada $\mathrm{BI}$ dan $\mathrm{HI}$ kelompok perlakuan, sedangkan $\mathrm{Cl}$ penurunannya tidak terlalu banyak. Aplikasi ovitrap selama 4 bulan ini dapat menurunkan $\mathrm{HI}, \mathrm{BI}$, dan $\mathrm{Cl}$ secara bermakna baik baik secara indeks tunggal maupun sebagai indeks gabungan (DI) seperti ditunjukkan dalam Tabel 2. Hal ini didukung oleh Gambar 2 yang menunjukkan terdapat kecenderungan menurunnya DI pada kelompok perlakuan dibandingkan pada kelompok kontrol.

Gabungan ketiga indeks tersebut (Density Figure/Index) juga menunjukkan bahwa kelompok perlakuan memiliki DI yang cenderung menurun dibandingkan kelompok kontrol seperti pada Gambar 2.

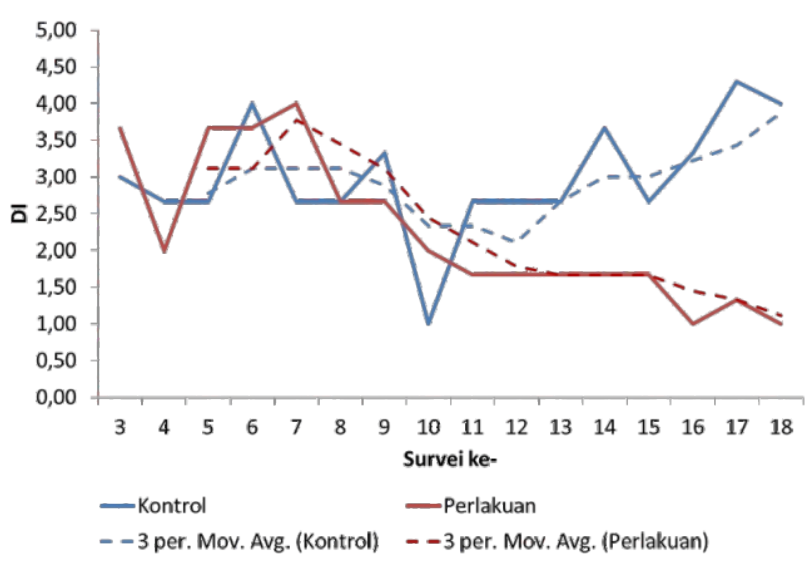

Gambar 2. Grafik moving average 3 mingguan Density Index

(DI). Aplikasi ovitrap dimulai pada survei periode 3

Perhitungan rata-rata jumlah telur per ovitrap di daerah perlakuan juga menunjukkan adanya penurunan yang tajam pada awal aplikasi baik pada ovitrap yang berada di dalam maupun di luar ruangan. Selanjutnya angka tersebut berfluktuasi sebagaimana halnya suhu dan curah hujan (Gambar 3).

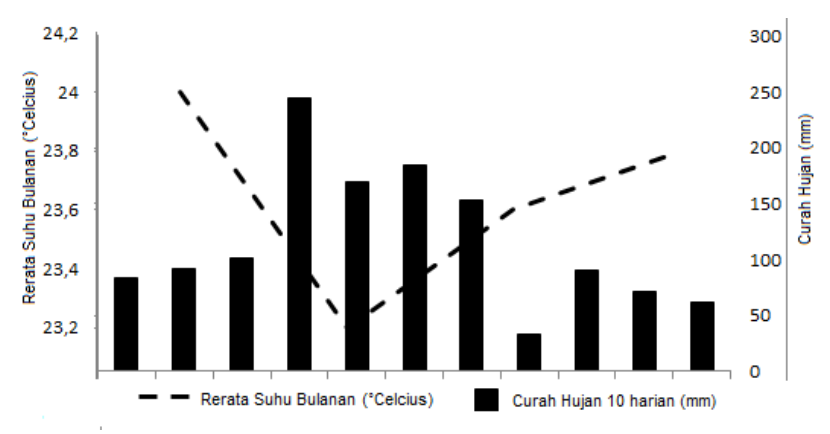

Gambar 3. Rata-rata jumlah telur per ovitrap per periode survei 


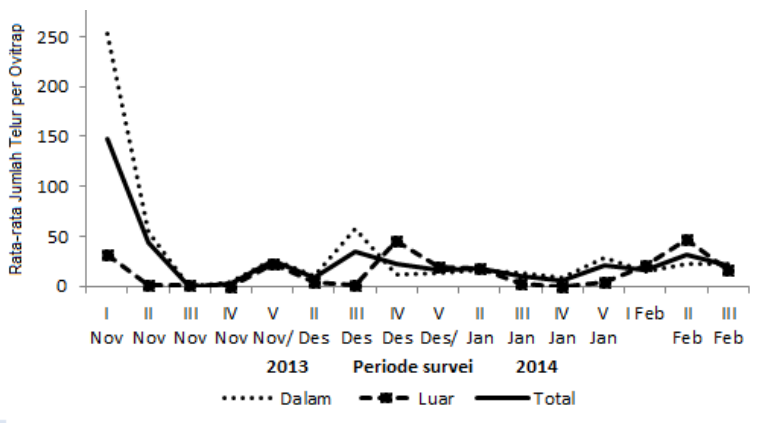

Gambar 3. Rata-rata jumlah telur per ovitrap per periode survei (Lanjutan)

Keterangan: Rata-rata jumlah telur per ovitrap selama 4 bulan: di dalam dan di luar ruangan $=26,4 \pm 34,3$; dalam ruangan $=34,8 \pm 60,4$; luar ruang= $14,8 \pm 16,1(\mathrm{~A})$; rata-rata suhu bulanan di Kota Malang $\left({ }^{\circ} \mathrm{Cel}\right.$ cius) selama penelitian berlangsung (B) dan curah hujan $(\mathrm{mm})$ per 10 harian di Kecamatan Sukun (Kelurahan Bandulan dan berdekatan dengan Kelurahan Sumbersari) selama penelitian berlangsung (C)

Hasil identifikasi larva yang ditetaskan dari telur yang didapat dari sampling ovitrap menunjukkan bahwa tidak semua telur nyamuk yang didapat dari ovitrap menetas. Penetasan telur dari ovitrap di Sumbersari tampak lebih banyak dibandingkan dari Bandulan (Gambar 4).

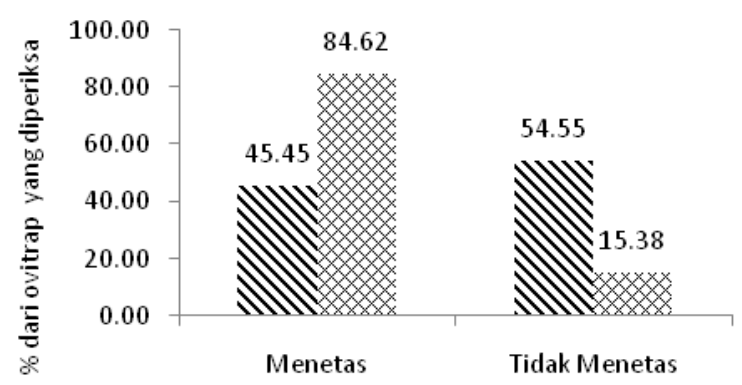

NBandulan \& Sumbersari

\section{Gambar 4. Persentase telur nyamuk yang menetas hasil dari sampel ovitrap}

Semua telur yang menetas tersebut baik dari Sumbersari maupun Bandulan merupakan telur dariAe.aegypti.

\section{DISKUSI}

Penyebaran DBD di Kota Malang tampak tinggi di kelurahan-kelurahan dengan padat penduduk yaitu di tengah kota hingga utara sedangkan di wilayah selatan kota Malang tampaknya masih dapat dikatakan relatif aman (Gambar 1). Wilayah ini pada umumnya masih belum padat penduduk. Di samping kepadatan penduduk wilayah, faktor lain yang perlu dipertimbangkan adalah kepadatan hunian rumah mengingat nyamuk Aedes lebih suka tinggal di dalam rumah. Dalam penelitian ini kepadatan hunian per rumah dapat dikatakan sebanding dimana tiap rumah dihuni oleh 4 orang baik untuk kelompok kontrol maupun perlakuan (Tabel 1). Kepadatan hunian lebih dari 4 orang per rumah dihubungkan dengan risiko DBD (23).

Aplikasi ovitrap di masyarakat memerlukan partisipasi yang tinggi dari masyarakat. Karena itu pertimbangan dari puskesmas mengenai tingkat partisipasi warga sangat diperlukan selain pertimbangan IR DBD. Penempatan ovitrap di sekolah tampaknya lebih dapat diandalkan daripada di rumah siswa atau kader. Hal ini mungkin karena sekolah adalah fasilitas umum yang tidak digunakan untuk tempat tinggal. Berbeda dengan rumah siswa atau kader dimana ovitrap ditempatkan di ruang tamu, bawah tangga, gudang, dapur, ataupun kamar yang memungkinkan orang-orang yang tinggal di dalamnya terganggu atau bahkan mungkin ingin mencobakan sesuatu pada ovitrap-nya. Observasi terhadap beberapa rumah yang mengaplikasikannya menunjukkan bahwa masyarakat belum sepenuhnya peduli dengan aplikasi ovitrap di rumahnya. Karena itu diperlukan pengetahuan dan kesadaran yang tinggi dari masyarakat apabila akan mengaplikasikasikan ovitrap secara mandiri. Hal ini mengingat aplikasi ovitrap memerlukan komitmen yang tinggi baik untuk perawatannya maupun monitoringnya. Apabila perawatan dan monitoring ovitrap tidak berjalan baik maka ovitrap dapat menjadi tempat perkembangbiakan baru (24).

Aplikasi ovitrap pada kelompok perlakuan berhasil menurunkan $\mathrm{HI}$ menjadi 2,9\% dan $\mathrm{Cl}$ menjadi 4,63\% pada akhir periode. Angka ini berada di area safety zone (kurang dari $10 \%)$ untuk penularan Yellow Fever yang vektornya adalah juga Ae. aegypti. Namun Soper memberinya batasan 5\%. Begitupula dengan $\mathrm{BI}$, di akhir periode $\mathrm{BI}$ turun menjadi 2,9 (kurang dari 5). Indeks gabungan ketiganya (DI) juga menunjukkan bahwa DI pada akhir periode mencapai angka 1 (Gambar 2). Pada angka BI kurang dari 5 dan $\mathrm{DI}=1$ ini tidak terjadi penularan Yellow Fever (9).

Penurunan $\mathrm{HI}, \mathrm{BI}$, dan $\mathrm{Cl}$ sebesar 13,14\%, 17,34, dan 4,81\% ini lebih besar dibandingkan kelompok kontrol (Tabel 2). Meskipun penurunan $\mathrm{Cl}$ pada kelompok perlakuan adalah terkecil dibanding dua index lainnya, namun masih lebih baik dibanding kelompok kontrol yang $\mathrm{Cl}$-nya semakin meningkat. Dengan lebih banyaknya kontainer yang positif larva maka risiko penularan DBD-pun semakin meningkat. Penurunan terbesar dialami oleh $\mathrm{BI}$ yang menunjukkan bahwa jumlah kontainer positif larva per 100 rumah menurun sebesar 17,34. BI merupakan indeks yang lebih baik dibandingkan Adult Productivity Index (API) (9). Hasil ini lebih baik dibandingkan dengan penelitian Sayono di Semarang, yang penurunannya hanya sebesar 7\%, 2, 5\% untuk $\mathrm{HI}, \mathrm{BI}, \mathrm{Cl}$ secara berurutan pada uji coba yang dilakukan selama 1 bulan (25). Pada penelitian ini penurunan terbesar dialami oleh $\mathrm{BI}$, sedangkan pada penelitian Sayono penurunan terbesar dialami oleh $\mathrm{HI}$. Aplikasi ovitrap model Kepanjen ternyata juga menghasilkan perbedaan $\mathrm{HI}, \mathrm{BI}, \mathrm{Cl}$, dan DI yang bermakna antara kelompok kontrol dan kelompok perlakuan. Hasil penelitian ini sejalan dengan penelitian Sayono yaitu $\mathrm{HI}$ dan $\mathrm{BI}$ juga berbeda antara kelompok kontrol dan kelompok perlakuan (25).

Ovitrap juga dapat berfungsi sebagai alat surveilans yang dapat mendeteksi kejadian DBD lebih baik dibandingkan survei larva, meskipun kadang terjadi overestimasi. Namun hal ini kurang efisien untuk keperluan tindakan pencegahan karena sumber daya yang ada sangat terbatas. Ovitrap bahkan bisa menunjukkan hasil yang sama dengan mosquito trap dalam hal spatial (ruang dan waktu) klaster DBD meskipun keakuratannya sedikit kurang dibandingkan mosquito trap karena periode durasi yang lebih lama (14). Hal ini karena perlu waktu minimal 1 
siklus mulai dari telur hingga menjadi nyamuk yang dapat menularkan. Penelitian de Resende et al di Brazil pada 2013 juga menyebutkan adanya korelasi positif antara indeks hasil ovitrap, survei larva, dan mosquito trap (26). Penyajian data rata-rata jumlah telur yang diperoleh per per ovitrap per periode akan lebih menggambarkan kondisi yang riil dibandingkan hanya menyajikan keberadaan telur di ovitrap (Ovitrap Index). Penelitian ini menunjukkan bahwa rata-rata jumlah telur yang diperoleh dari ovitrap per periode selama 4 bulan aplikasi berfluktuasi. Pada awal periode aplikasi angka tersebut tinggi yaitu 147,09 telur per ovitrap sedangkan di akhir periode aplikasi angka tersebut turun menjadi 20,33 telur per ovitrap. Angka di akhir periode ini lebih rendah dibandingkan rata-rata jumlah telur selama 4 bulan yaitu 26,39 telur per ovitrap (Gambar 3). Penurunan rata-rata jumlah telur yang tajam ini kemungkinan disebabkan banyaknya telur yang tertangkap pada awal periode gagal menetas menjadi nyamuk dewasa sehingga pada periodeperiode berikutnya jumlah telur yang dihasilkan menurun.

Angka yang diperoleh dari 16 kali (4 bulan) pengambilan pada penelitian ini lebih besar dibandingkan perolehan telur ovitrap yang menggunakan air ledeng di Kamboja yaitu 4,76 telur per ovitrap selama 1 bulan (13 kali pengambilan) (10) dan perkiraan jumlah telur ovitrap di Pahang, Malaysia (27) yang mempertimbangkan jumlah

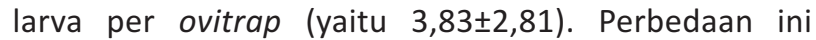
kemungkinan karena diameter ovitrap pada penelitian ini lebih besar dibandingkan diameter pada kedua penelitian tersebut sehingga peluang sebagai tempat oviposisi nyamuk semakin besar. Tingginya rerata jumlah telur per ovitrap di awal intervensi ini tampaknya sejalan dengan tingginya rerata suhu bulanan namun berbanding terbalik dengan rendahnya rerata curah hujan 10 harian. Saat pertengahan intervensi rerata jumlah telur per ovitrap menurun dan selanjutnya berfluktuasi diikuti dengan menurunnya rerata suhu bulanan, dan meningginya rerata curah hujan 10 harian yang juga berfluktuasi (Gambar 3). Hasil ini hampir sama dengan temuan di Brazil yaitu jumlah telur nyamuk berkorelasi positif dengan suhu namun berkorelasi negatif dengan curah hujan (26). Temuan agak berbeda didapatkan dari penelitian di Brazil yang menunjukkan rata-rata jumlah telur ovitrap berkaitan dengan suhu dan curah hujan 2 sampai 4 minggu sebelumnya (28). Aplikasi ovitrap untuk di luar ruangan rumah/kelas ternyata menghasilkan rata-rata jumlah telur per ovitrap yang lebih sedikit dibandingkan ovitrap di dalam ruangan. Pada awal aplikasi selisih tersebut sangat besar karena perolehan ovitrap dalam ruangan lebih banyak dibandingkan untuk luar ruangan. Namun pada periode-periode selanjutnya angkanya berfluktuasi meskipun pada sebagian besar periode perolehan telur ovitrap di dalam ruangan sedikit lebih banyak dibandingkan ovitrap di luar ruangan (Gambar 3). Nyamuk Ae. aegypti lebih menyukai tinggal di dalam ruangan daripada di luar ruangan karena nyamuk dewasa cenderung untuk beristirahat pada pakaian dan permukaan di dalam rumah sehingga nyamuk betina sering menggigit manusia (29).

Dari hasil penetasan telur sampel ovitrap didapatkan bahwa persentase telur yang menetas lebih besar untuk Sumbersari dibandingkan Bandulan (Gambar 4). Hal ini mungkin karena sebagian besar RT di Bandulan merupakan kawasan perumahan yang menggunakan air ledeng sehingga untuk aplikasi ovitrap juga menggunakan air ledeng, sedangkan Sumbersari merupakan kawasan perkampungan dengan sebagian besar warga masih menggunakan air sumur sehingga untuk aplikasi ovitrap juga menggunakan air sumur. Air sumur merupakan media yang baik bagi telur nyamuk untuk menetas dibandingkan air ledeng $(19,30)$. Hal ini kemungkinan karena air sumur tidak mengalami klorinasi. Sebaliknya klorinasi pada air ledeng dapat menghambat penetasan telur nyamuk, larvae, bahkan pupa (31).

Jenis larva yang menetas dari telur yang diperoleh dari ovitrap pada penelitian ini semuanya adalah Ae. aegypti. Penggunaan air bersih untuk ovitrap dan lebih tingginya perolehan telur dari dalam ruangan berpeluang tinggi mendapatkan nyamuk Aedes saja karena Aedes memang menyukai air bersih. Nyamuk Aedes dapat bertelur di sekeliling bagian tengah kain nylon/kertas saring yang lembab karena tercelup air. Dominasi Ae. Aegypti yang didapatkan dari ovitrap ini menunjukkan bahwa $A e$. Aegypti merupakan spesies yang penting dalam penyebaran DBD di kedua kelurahan tersebut sebagaimana didapatkan juga di Taiwan (16) dimana ovitrap hanya ditempatkan di luar rumah dan di Mexico dimana ovitrap ditempatkan di dalam dan luar rumah (32). Sebaliknya aplikasi ovitrap di Semarang yang menghasilkan banyak telur dari luar rumah mendapati spesies nyamuk yang banyak ditemukan adalah $A e$. albopictus. Hal ini karena aplikasi ovitrap berdekatan dengan lahan atau pekarangan kosong (26).

Penggunaan ember warna hitam meskipun tanpa atraktan (hanya air ledeng/sumur) sebagai ovitrap ternyata mampu menarik nyamuk untuk bertelur di ovitrap dibandingkan di kontainer lainnya seperti kamar mandi, gentong, dan lainlain. Warna hitam terbukti lebih menarik nyamuk $A e$. albopictus untuk bertelur dibandingkan warna lainnya. Kemungkinan besar Ae. albopictus mempunyai kesamaan kesensitifan terhadap warna yang sama dengan $A e$. aegypti karena kedua spesies ini memiliki kebiasaan waktu menggigit yang sama (33). Begitu pula dengan penggunaan nylon warna terang yaitu krem sebagai penutup ovitrap tidak mempengaruhi nyamuk untuk bertelur. Hal ini sama dengan yang didapat oleh Santoso et al (34).

Dapat disimpulkan bahwa dalam waktu 4 bulan aplikasi ovitrap model Kepanjen ini dapat menurunkan angka kepadatan jentik Ae. aegypti yang ditandai dengan menurunnya $\mathrm{HI}, \mathrm{BI}, \mathrm{Cl}$, dan $\mathrm{DI}$. Ovitrap ini dapat menjadi alternatif murah pengendalian vektor DBD mengingat volumenya yang besar, bahan-bahannya mudah didapat, dapat menggunakan air ledeng atau sumur saja, serta instalasinya sederhana. Namun demikian aplikasi ovitrap sebaiknya dilakukan pada penelitian yang terpantau oleh peneliti saja mengingat masih rendahnya pengetahuan dan kesadaran masyarakat terhadap ovitrap.

\section{UCAPAN TERIMA KASIH}

Peneliti menyampaikan terima kasih kepada Dekan dan para Wakil Dekan Fakultas Kedokteran Universitas Brawijaya; Kepala Laboratorium Parasitologi, yang telah memfasilitasi terlaksananya penelitian ini. dr. Aswin Djoko B, Sp.Par.K, dr. Sudjari, DTM\&H, M.Si. Sp.Par.K, mas Budi, mbak Heni dan para mahasiswa yang membantu jalannya penelitian; dan DIKTI melalui Program Hibah Kompetisi Peningkatan Kualitas Pendidikan Dokter (PHK PKPD) Fakultas Kedokteran Universitas Brawijaya sebagai pemberi dana penelitian. 


\section{DAFTAR PUSTAKA}

1. Badan Penelitian dan Pengembangan Kesehatan Departemen Kesehatan Republik Indonesia. Riset Kesehatan Dasar (RISKESDAS) 2007. Laporan Nasional 2007. Jakarta: Depkes RI; 2008.

2. Dinas Kesehatan Provinsi Jawa Timur. Profil Kesehatan Provinsi Jawa Timur Tahun 2012. Surabaya: Dinkes Provinsi Jawa Timur; 2013.

3. Penyakit dan Penyehatan Lingkungan Dinas Kesehatan Kota Malang. Laporan DBD. Malang: Dinkes Kota Malang; 2011.

4. Penyakit dan Penyehatan Lingkungan Dinas Kesehatan Kota Malang. Laporan DBD. Malang: Dinkes Kota Malang; 2013.

5. Badan Pusat Statistik Kota Malang. Malang Kota dalam Angka 2012. Malang: BPS Kota Malang; 2012.

6. Badan Pusat Statistik Kota Malang. Malang Kota dalam Angka 2012. Malang: BPS Kota Malang; 2013.

7. Badan Pusat Statistik Kota Malang. Malang Kota dalam Angka 2012. Malang: BPS Kota Malang; 2014.

8. World Health Organization. Dengue. Guidelines for Diagnosis, Treatment, Prevention and Control. New Edition. Geneva: World Health Organization; 2009.

9. Focks DA. A Review of Entomological Sampling Methods and Indicators for Dengue Vectors. Special Programme for Research and Training in Tropical Diseases. Geneva: World Health Organization; 2003.

10. Polson KA, Curtis C, Seng CM, Olson JG, Chantha N, and Rawlins SC. The Use of Ovitrap Baited with Hay Infusion as a Surveillance Tool for Aedes aegypti Mosquitoes in Cambodia. Dengue Bulletin. 2002; 26: 178-184.

11. Santos SRA, Melo-Santos MAV, Regis L, and Albuquerque CMR. Field Evaluation of Ovitrap with Grass Infusion and Bacillus thuringiensis var israelensis to Determine Oviposition Rate of Aedes aegypti. Dengue Bulletin. 2003; 27: 156-162.

12. Facchinelli L, Koenraadt CJ, Fanello C, et al. Evaluation of a Sticky Trap for Collecting Aedes (Stegomyia) Adults in a Dengue-endemic Area in Thailand. The American Journal of Tropical Medicine and Hygiene. 2008; 78(6): 904-909.

13. Ooi EE, Goh KT, and Gubler DJ. Dengue Prevention and 35 Years of Vector Control in Singapore. Emerging Infectious Diseases. 2006; 12(6): 887-893.

14. Morato VCG, Teixeira MG, Gomes AC, Bergamaschi $\mathrm{DP}$, and Barreto ML. Infestation of Aedes aegypti Estimated by Oviposition Traps in Brazil. Revista de Saúde Pública. 2005; 39(4): 553-558.

15. Ho CM, Feng CC, Yang CT, et al. Surveillance for Dengue Fever Vectors Using Ovitraps at Kaohsiung and Tainan in Taiwan. Formosan Entomology. 2005: 25: $159-174$

16. Fay RW and Perry AS. Laboratory Studies of Ovipositional Preferences of Aedes aegypti. Mosquito News. 1965; 25(3): 276-281.

17. Lok CK, Kiat NS, and Koh TK. An Auto Cidal Ovitrap for The Control and Possible Eradication of Aedes aegypti. Southeast Asian Journal Tropical Medicine and Public Health. 1977; 8(1): 56-62.

18. Puspita H. Kepala Puskesmas Kepanjen. Personal Communication. 20 September 2013.

19. Zuhriyah L, Sudjari, dan Pawestri AR. Evaluasi Efektivitas Ovitrap Kepanjen dan Modifikasinya dengan Variasi Atraktan pada Skala Laboratorium dan Komunitas. [Laporan Penelitian Program Hibah Kompetisi Peningkatan Kualitas Pendidikan Dokter (PHK PKPD)]. Universitas Brawijaya, Malang. 2014.

20. World Health Organization Regional Office for the Western Pacific. Guidelines for Dengue Surveillance and Masquito Control. 2nd Edition. Manila: WHO; 2003.

21. Badan Pusat Statistik Kota Malang. Kecamatan Lowokwaru dalam Angka 2014. Malang: BPS Kota Malang; 2014.

22. Badan Pusat Statistik Kota Malang. Kecamatan Sukun dalam Angka 2014. Malang: BPS Kota Malang; 2014.

23. Koyadun S, Butraporn P, and Kittayapong P. Ecologic and Sociodemographic Rsk Determinants for Dengue Transmission in Urban Areas in Thailand. Interdisciplinary Perspectives on Infectious Diseases. 2012; 2012: 12.

24. Rapley LP, Johnson PH, William CR, et al. A Lethal Ovitrap-Based Mass Trapping Scheme for Dengue Control in Australia: II. Impact on Populations of the Mosquitoaedes Aegypti. Medical and Veterinary Entomology. 2009; 23(4): 303-316.

25. de Resende MC, Silva IM, Ellis BR, and Eiras AE. A Comparison of Larval, Ovitrap and Mosquitrap Surveillance for Aedes (Stegomyia) Aegypti. Memórias do Instituto Oswaldo Cruz. 2013; 108(8): 1024-1030.

26. Sayono, Santoso L, and Adi MS. Pengaruh Modifikasi Ovitrap terhadap Jumlah Nyamuk Aedes yang Terperangkap. Media Kesehatan Masyarakat Indonesia. 2009; 8(1): 49-57.

27. Norzahira R, Hidayatulfathi O, Wong HM, et al. Ovitrap Surveillance of the Dengue Vectors, Aedes (Stegomyia) aegypti (L.) and Aedes (Stegomyia) albopictus Skuse in Selected Areas in Bentong, Pahang, Malaysia. Tropical Biomedicine. 2011; 28(1): 48-54.

28. Mackay AJ, Amador M, and Barrera R. An Improved Autocidal Gravid Ovitrap for the Control and Surveillance of Aedes Aegypti. Parasites \& Vectors. 2013; 6: 225

29. Rothman AL. Dengue Virus. New York: Springer; 2010.

30. Sayono, Qoniatun S, dan Mifbakhuddin. Pertumbuhan Larva Aedes aegypti Pada Air Tercemar. Jurnal Kesehatan Masyarakat Indonesia. 2011; 7(1): 15-22.

31. Ritchie SA. Efficacy of Australian Quarantine Procedures Againts the Mosquito Aedes aegypti. Journal of the American Mosquito Control Association. 2001; 17(2): 114-117.

32. Lenhart $A E$, Walle $M$, Cedillo $H$, and Kroeger $A$. Building a Better Ovitrap for Detecting Aedes aegypti Oviposition. Acta Tropica. 2005; 96(1):56-59

33. Hoel DF, Obenauer PJ, Clark M, et al. Efficacy of Ovitrap Colors and Patterns for Attracting Aedes Albopictus at Suburban Field Sites in North-Central 
Florida. Journal of the American Mosquito Control Association. 2011; 27(3): 245-251.

34. Santoso J, Hestiningsih R, Wardani RS, and Sayono.
Pengaruh Warna Kasa Penutup Autocidal Ovitrap terhadap Jumlah Jentik Nyamuk Aedes aegypti yang Tertangkap. Jurnal Kesehatan Masyarakat Indonesia. 2007; 4(1): 85-90. 